\title{
Tozzi, Automatism, and Epistemology
}

Pare che pensi anche il mio corpo.

(Federigo Tozzi, Novale)

A large amount of criticism has examined the work of Federigo Tozzi, showing care in repeating the positive revaluation of the "autobiographical" works as opposed to the "objective" novels; with a continued insistence on the unconscious or involuntary processes at work in the composition of those "autobiographical" writings. This has, up to the present, directed critical approaches to Tozzi, though it no longer besets most judgements of value. For example, Giacomo Debenedetti, the author of what is still the most acute reading of Tozzi and the critic most responsible for the reanimation of Tozzian studies, asserted: "Il naturalismo rappresenta in quanto spiega, e viceversa; Tozzi rappresenta in quanto non sa spiegare" (154). A much quoted, benign aphorism which, after all, explains little, inasmuch as even a naturalist might eschew an expository style in unfolding some parts of human experience, and consciously avoid what Joyce called "wideawake language, cutandry grammar and goahead plot."1 There is, however, still a constant attribution to Tozzi of a deficiency in analysis which has led to a critical impasse. ${ }^{2}$ Not that Tozzi did not have a hand, of course, in this equivocation. In fact I would like to underline that responsibility here. In scrutinizing the weight given by critics to elements of "automatism" in Tozzi's composition it is perhaps superfluous to repeat the Sienese author's own emphasis on the impenetrable and the mysterious; the very title of his most famous work, Con gli acchi chiusi; the seeming absence of extended self-commentary and analysis. It is an understatement to say that Tozzi rarely dwells on the conscious compositive process in his letters, critical writings, or works like Bestie in which the narrator may at times, with some justification, be confused with the author. ${ }^{3}$ On the contrary he is often at pains to assert his own inability to repeat in other words what he has done. And even the most positive critics have continued to repeat that Tozzi was somehow incapable of dominating, of controlling, his material. The judicial spectrum that influenced these apologetic lapses was formed by, among others, Luigi Russo, Natalino Sapegno and Debenedetti; judgements 
which range, on the one side, from attributing, as does Sapegno, to the writer a total incapacity to objectify his psychological experience into narrative form, and actually refusing to rate his work as art, to, on the other, oddly making that very incapacity the foundation for appraising Tozzi as one of our century's greatest literary artists. ${ }^{4}$ Clearly these two propositions are incompatible. And it is not clear how one can be a great artist because of an insufficience. What is most important, however, is the fact that neither view has allowed us to procede very far.

What were the inadequacies imputed to Tozzi? In rough outline, they can be described in the following terms. First, a "naif" author incapable of analysis of psychological states, his own or of his characters, he was largely unable to unbind himself from his own autobiography to create works which are artistic entities in themselves. 5 Second, incognizant of the import of his creation (according to these early critics), he was not a deliberate and conscious artist; nearly everything in Tozzi is gratuitous, or at least largely involuntary. Again, we must refer to Debenedetti who tempered, but did not completely eradicate, these errors, in placing Tozzi as supreme artist largely because of these failings. That is, Debenedetti, I feel, did not go quite far enough, in correcting the misconception, which remains, that a lack of conscious control is responsible for most aspects which define Tozzi. ${ }^{6}$ We are indebted to Debenedetti in that subsequent critical discourse has begun with the assumption that Tozzi occupies a key position in the evolution of the novel, and for pointing out the Januslike quality of Tozzi's work, which in certain respects looks back to traditional practise, and in other respects looks forward to future developments, in particular the "existential" novel. Tozzi, like Flaubert, is quite torn between supporting and subverting the novel as form, and also similar in his thematic obsession. So it is that minimal part of Debenedetti, and the critics who have echoed that part of him with which I cannot agree, that will be examined here; for the rest, he is required reading for anyone hoping to find a reasoned evaluation of the Sienese author.

In a reading of Bestie, Debenedetti (68-72) comments on the piece in which Tozzi alludes to his vocation as artist. The narrator recounts studying intently as a child the work of a carriagemaker as he paints with lead oxide and vermilion the wheels of the farmers' carts. The narrator then considers:

Pensavo, allora, che da grande avrei scritto un libro differente a tutti quelli che io conoscevo: qualche storia ingenua e tragica che pareva uno di quei pampini che il vento mi faceva cadere fra la ginocchia; ecco: come c'è questo pampino, ci sarà il mio libro. (Opere 611)

Debenedetti invites us to consider as unconscious, unwitting, on the part of both boy and author, this analogy between the sure, reflexive artisan-like mastery of the carriagemaker and the projected work of the artist. Why unwitting? 
As usual with Tozzi, the artisan's work and materials are described minutely, even to the deft use of the brush handle to remove a fly which has stuck to the wet pigment. And Debenedetti presents this as a comparison between the anxious, in fact, anguished writer unsure of his powers and of his success, and the calm, nearly involuntary work of the laborer. However it is always an unconscious comparison, according to the critic. In an aside, Debenedetti repeats the notion that, in any text, the images expressed always say more than the author intended, and form meanings beyond what the author has proposed to himself in evoking them: an unlimited semiosis. And surely this is so. But why to such a degree in this particular case, and in Tozzi's work overall? Tozzi uses the comparison of his book and the vineleaf which falls between his knees. Debenedetti calls this "un sogno di oggettività"; the material given the artist directly from life must gain meaning outside of his life, and the autobiographical cease to appear autobiographical, or to behave as such. It seems to me that Tozzi is here thinking precisely, and quite consciously, like the artisan to whom the idea of signing his work never occurs, but whose effort is no less cognizant and no less a source of personal pride for that. This is one sense of the simile "pampino" or vineleaf in the above citation from Bestie: not that the work has dropped incontrollably or automatically from its author, but that Tozzi (like the anonymous artisan) does not willingly examine the conscious creative process in or outside the work of art, seemingly uninterested in the formation of a book; certainly not enough to allude to it in the book itself. The book appears to its readers like the vineleaf, a spontaneous creation of Nature which has in turn been set in motion by some deus absconditus who has willed everything. Note that not even in Ricordi di un impiegato, where there is the fiction of a diary, and therefore of a writer, Leopoldo, are the themes of form, expression or writing once mentioned. I will also compare this later on to Svevo, with whom Tozzi is often and unfortunately compared; for the moment it is enough to mention that Tozzi venerates a finished work as a thing apart from himself, which in some sense it is, lucidly generated by him but no longer belonging to him: a reluctance or refusal, perhaps, to discuss the artistic process, which has mistakenly been taken as a thaumaturgic fear, or incapacity.

In Tozzi's diaries and journals, even those written as a young autodidact frequenting the public libraries, there is almost no mention of books, nor of ideas. Instead Tozzi records, to excess, sensual impressions. A typical entry reads:

Una ragazza è seduta sui barili legati sopra il suo carro, appuntando i piedi alla inforcatura del timone. E' stata così tutto il tempo della fiera; quando è cominciato a piovere ha aperto un ombrello verde, appoggiandoselo su le ginocchia e su la fronte.

Si cacciava le dita dentro le narici. (Cose 381)

In these notations concerning sounds, sights and smells, Tozzi seldom registers 
his thoughts as such. Or rather, his thoughts are a series of imagery. "Io posso sentire i miei occhi che guardano o parlano silenziosamente con la mia anima" (Opere 603): the things the poet sees become words without the mediation of the intellect. On a rare occasion when he sets down a few lines of abstract remarks they are immediately disallowed:

Quel che ho scritto sopra circa il cattolicismo (subito dopo mangiato fumando una sigaretta) non è che un'astrazione per reintegrare automaticamente un viluppo di pensieri erranti, uno scarto di idee macchinali senza un vero significato per me, una punta per interpretare il modo di pensare, uno studio del cattolicisnı. (Cose 382)

"Non è che un'astrazione," "un viluppo di pensieri erranti;" "uno scarto di idee macchinali:" one feels that for Tozzi "interpretare" is pejorative. In some of his critical writing and journalism, his most raw invective is reserved for the language of the critic: "i rognosi e stiracchiati giudizi dei nostri pedagoghi;" "sciochezze piatte e rincalgnate;" "scombiccherare di bave cascanti," professorume;" and the eloquent "fili di ragnatela ribolliti nell'acqua dei cavolfiori." 7 Writing of the use of abstraction, in an acute article on Pirandello from 1918, Tozzi, while expressing admiration for the author, registers the distance between them in terms of style. Pirandello's prose "non è una prosa che prende vita dalle parole, ma sono le parole che prendono vita da quel che è dentro." Tozzi's impression is that of "un addentellato continuo di astrazioni verosimili," the "impressione di un mondo astratto" where characters move who seem "addiritura larve e immagini di supposizioni" (Opere 1313-19). This style, Tozzi continues, may work when adopted by a Pirandello, but lesser writers, as we read in Tozzi's essay "Come leggo io," "pigliano di squincio le parole; le adoperano, cioè, non perchè siano stati costretti a scegliere quelle e non altre. Le adoperano con una psicologia approssimativa" (Opere 1324-27).

It is just this "psicologia approssimativa" that is entirely absent in Tozzi, so far at the antipodes that we might say that, for him, language itself is unacceptably approximative, or else constantly shifting in its ties with reality. He often feels an acute difficulty in connecting names and things, so that words seem, at one moment, to lack any referent, and the next to weigh so heavily on things that they seem like prisoners' chains, or even cause forgetfulness like absinthe, as in this passage from the story "In campagna:"

"Egli passava da una parola all'altra, con un senso di stanchezza. Le parole gli scorrevano l'anima come una catena di accaio. Oppure erano lontane da lui, trasparenti e leggiere: un complesso che non lo riguardava. [...] Vedeva cadere le proprie parole come cose pesanti, come cose misteriose. Una parola per lui era come una pietra. Talvolta gli pareva che essa fosse, per la sua anima, come un velo trasparente, del quale si moveva soltanto la superficie. Ed anche la gustava come un assenzio. Egli la beveva come un sentimento, che prendeva una solidità immobile." (Opere 1042-43) 
Certainly, in Tozzi, any signifier or set of signifiers not referring to an absent object perceivable to the senses, or a nominative or nominative construct (which the author favors) is scrutinized, suspect. The tangible, itself under suspicion like all else in the Tozzian world predominates absolutely in his prose, as if out of fear. The effect on his style is total. Saccone comments: "...i significanti non solo sono in piena evidenza, richiamanti l'attenzione su di sé, ma più in generale il visibile, l'evidenza messa sotto gli occhi del lettore, si accende di uno splendore - e uno spessore - ippereale" (Saccone "Allegorie" 88). This description is exact. Tozzi's description of the fictive world of Grazia Deledda fits his own: "un sogno avvenuto sotto una luce esasperata" (Opere 1288). Unfortunately the same "eccesso di sensazioni" in Tozzi's prose has produced a superabundance of critical interpretations that emphasize his lack of control; in the worst of cases, as with Russo or Sapegno, of lack of artistry. Once the idea is admitted that automatism (lack of conscious control) provides us with the key to the artist's work, or the quality of that work, there is a demand for convincing documentation which, if it fails to demonstrate automatism in the artist, may, however, lead to the charge of automatism in the critic himself. Instead, Tozzi used his artistry to create the new prose described by Saccone, a prose which, Tozzi writes in Realtà di ieri e di oggi, a writer "invece di fare molto agevolmente l'istrione, menando i [...] personaggi per quelle fila che sono repetute indispensabili a un buon romanziere...." wishes to "lasciare inalterati, così come sono e si presentano in una qualunque porzione di realtà guardata, tutti gli elementi della vita" (Realtà 90).

Why would an artist do this? At times Tozzi's goal seems less artistic than epistemological. For in the tireless catalog of "porzioni di realtà guardata" mainly notations of visual data - that forms Bestie, he seems to be giving preliminary form to an epistemology. That is, in endlessly collecting narrative exempla, Tozzi appears to be looking for a primitive or intuitive truth (the clear and distinct notation of the external world) on which to base some general affirmation. But there is an endless suspicion that negates the reliability of that data; the figure of interrogatio, or questioning, which predominates in his work nearly takes Tozzi to a position akin to what we call skepticism. But the principle goal of skepticism is mental imperturbability by way of a suspension of judgement: truth is not an ultimate goal. I am not suggesting that Tozzi was consciously pursuing philosophy, or that he was well versed in philosophy. His work, however, is full of more or less formulated primitive epistemological questions in which doubt and suspension of judgement are main features. Looking at his own work, Tozzi does not even share the Viconian sense of verum ipsum factum: that the condition of knowing an object, a book, an institution, is having created it. In other words, if it is true that only God can have entire knowledge of things, because only $\mathrm{He}$ is Creator - as Croce writes of Vico's gnoseology "a Dio creare, all'uomo il solo cogito" - then man will go 
endlessly gathering elements of reality, without ever gathering all, without, in short, summing up. This is a description of human cognition (which is never complete), and I think also a description of Tozzi's poetic operation. To God intellegere, to man cogitare: a proclamation of simple consciousness, infinitely repeated. The certainty, the truth of consciousness, is not science, but is not therefore false; the one truth of simple cognition is the repeated indication of being. So that Tozzi's endlessly varied descriptions of reality, clear as they appear, are rather descriptions of his own psychology than a means of appropriation. And like Greek runner Achilles who infinitely draws nearer to, but never reaches his competitor, Tozzi is always in the act of approaching, but never appropriating, that reality. His is an anatomy, a cataloging, not an explanation.

It has been said that Tozzi is incapable of forming a coherent intellectual discourse. 8 If by "intellectual" is meant "abstract" or critical, then it would seem, rather, that his is a refusal. Tozzi shows every sign of consciously and vehemently rejecting abstract analysis as operating procedure. He suspiciously barricades himself at the antipodes. And he carries this so far as to deliberately place into relief and subvert that absolute abstraction, time. In Con gli occhi chiusi, for instance, though he presents the physical growth of the protagonist from childhood to youth to adolescence, Tozzi seems to wish to undermine any sense of historicity: narrative fragments are separated by asterisks; scene after scene begins with "talvolta" or is presented in the imperfect form which might signify a temporally unfocused past; and at one point the narrator, wholly unexpectedly, appears in the first person and just as promptly disappears. Mentioning time, in Realtà di ieri e di oggi Tozzi writes: " $E$ ' necessario convincerci che il nostro pensiero non lega l'avvenire al presente, ma il presente al presente" (54). And in fact the recurrent use of the imperfect as a narrative tense may diminish the sense of a history, presenting, rather, a cadence ruled by a capricious memory. For Pietro, protagonist of Con gli occhi chiusi, the substantial or sensual world is keenly registered, but there is not that capacity for generalization which would produce temporal or conceptual continuity and render the world a soluable enigma:

Si sforzava d'essere soddisfatto e di affezionarsi alla scuola; ma gli pareva che i giorni fossero così staccati e separati l'uno dall'altro che sentiva prendersi dallo scoraggiamento. Il giorno dopo non era capace più a ricordarsi e a raccapezzarsi del giorno avanti; e provava difficoltà a pensare ai giorni successivi. (Opere 94 )

And again, in Bestie (Opere 94): "Quando penso che io sono fatto di tante strisce che corrispondono ad altrettanti giorni, mi domando se esisto io o le cose che ora ho dinanzi agli occhi. E mi domando cosa significa vivere." We know from Novale that Tozzi found, in the work of William James and other psychologists, confirmation of what his own poetic intuition had suggested concerning the brevity of, and fragility of, psychological states and the 
susequent lack of a sense of unified identity. ${ }^{9}$ As with so many passages of Tozzi's work, it is difficult to see how the composer of this analysis could be so entirely confused, by so many critics, with his nonplussed protagonist.

It helps to think back to the book that the young narrator of Bestie, observing the carriagemaker, dreams of one day writing: a book both "differente a tutti" and "ingenuo." Different from every other because it is naive? Could the naiveté then be willed? The Irish poet Yeats, who in contrast with Tozzi was explicit and programatic with his claims of automatism, particularly in $\mathrm{A} \mathrm{Vi}$ sion, recalls in that book what is, after all, a platitude concerning poetic composition:

There is a letter of Goethe's, though I cannot remember where, that explains evocation, though he was but thinking of literature. He described some friend who had complained of literary sterility as too intelligent. One must allow the images to form with all their assuciations before one criticizes. "If one is critical too soon," he wrote, "they will not form at all." If you suspend the critical faculty, I have discovered, either as a result of training, or, if you have the gift, by passing into a slight trance, images pass rapidly before you. If you can suspend also desire, and let them form at their own will, your absorption becomes more complete and they are more clear in colour, more precise in articulation, and you and they begin to move in the midst of what seems a powerful light (Yeats 49).

Many critics have noted the extremely vivid and precise visual imagery in Tozzi, calling certain evocations "visions" or "hallucinations" - words which suggest lack of control. Instead, Tozzi consistently recreates a program which negates analysis and invalidates theory. We see him following an analytic procedure the general terms of which he is permanently wary of setting out. He moves suspiciously, by metaphor, metonymy, allegory. In one of his last novels, Gli egoisti, Tozzi for the first time (apart from the brief allusions in Bestie) presents the figure of the artist, Dario Gavinai. It is the most analytical, and, we are told by the artist's son, Glauco Tozzi, the most planned book by his father; more important, it is the only novel which includes attempted examination of the creative process. Accordingly, the protagonist appears - at least compared to Remigio Selmi of Il podere or Pietro Rosi of Con gli occhi chuisi - to be "balanced;" Dario Gavinai has a lover, Albertina, and friends; in short he appears less a prisoner of his inner life (though, it might be said, victim) than other Tozzian figures. Of Dario, Tozzi writes: "Ma i ricordi della campagna doventavano sensazioni musicali e i pensieri di Dario erano suoni." His thoughts are pure sounds; allegorically, visual images. And in a passage of acute analysis, Tozzi continues:

Quando i suoni nascevano egli non poteva udirli subito; come se glielo impedisse una sordità implacabile; ma, un istante dopo, li percepiva con chiarezza, sebbene un poco più distanti. E poteva scriverli senza nessuno sforzo di attenzione. Gli era come proibito di 
prendere parte con la volontà a questa creazione; e si sentiva come costretto a obbedirle. (Opere 462)

Here we must state the obvious. Tozzi is describing the unmeditated act of creation known to many artists. It is very unlikely that this fictionalized analysis is itself a celebratory manifestation of that type of involuntary inspiration. I use the notion of celebration because there is no depreciatory tone whatsoever; Tozzi never speaks of this manner of working (which we should be wary of assuming is his own) as a handicap; on the contrary, there is a sense of exhaltation. "Pare che pensi anche il mio corpo," he writes in Novale. Not "only" but "also" the body. In a much quoted passage of a letter to his wife, Emma, dated July 25, 1918, Tozzi reports having completed Il podere:

Il libro è finito... lo non so quel che ho fatto. Non lo so. Mi sono provato a rileggere, ma non ci capisco niente. L'ho finito a mezzanotte. Ora mi viene la voglia di stracciarlo, come se mi dovessi vendicare di averlo scritto. Pensa che io non riesco a sapere che cosa è!... Ma deve essere bello, perché ho detto quel che da tempo sentivo che dovevo dire. (Cesarini 219)

The critics I have mentioned (and all others, as far as I am aware) always omit the rest of the letter. It would be well to cite further. Tozzi describes the finished work as "una cosa asciutta e arida che sia doventata molle ed esuberante": from abstraction to physicality, what the writer "doveva dire". He then goes on:

I personaggi di primo piano sono 5; altrettanti quelli di secondo e una dozzina gli altri. Ho preso parte intensamente alla loro esistenza; tanto che ci credo ancora. Ma bisogna assolutamente che riveda certi luoghi che per lettera non indico. Ora, mi è possibile discutere gli stati di animo dei personaggi; e quindi posso farli profondo quanto voglio e metterci quel che voglio...(219).

Instead of "automatic" writing or writing "under dictation," we have an author who vaunts (somewhat contradictorally, though contradiction itself is a way of subverting theory) of his total control of his material, who feels "un orgoglio ingenuo d'essere un creatore" (from a letter, also to Emma, dated two days before), and who is planning revisions of weak points which he is capable of singling out in his book. And it is clear that Tozzi, in the words of Debenedetti:

...vuol narrare, prendere i personaggi della vita, trasformarli in quei simulacri di cera che i maghi si fabbricano per le loro operazioni, trafiggerli, ferirli, piegarli in posizioni differenti dal vero, per restituirli trasformati, presi in un altro giro di destino, alla vita narrativa. (57)

And again, in Bestie Tozzi writes: "Ma ora avrei voglia di scrivere una novella, i cui personaggi fossero burattini" (Opere 594). 
We have gone from automatism to Flaubert. To insist, as do the critics mentioned, that for Tozzi, writing was the only way he could appropriate that reality which otherwise escaped his possession and understanding, that his is in some way a thaumaturgic exorcization, leads us to no specificity: the same might be said of scores of artists, including an author at the antipodes of Tozzi in terms of method. "On ne choisit pas son sujet," Flaubert writes. "Voilà ce que le public et les critiques ne comprennent pas. Le secret des chefs-d'oeuvre est là, dans la concordance du sujet et du temperament de l'auteur."10 We might turn the latter part of the statement around for Flaubert and say: the secret is often in the disconcordance between the subject imposed and the author's temperament, or what he believes his aim to be. Flaubert, much more than Tozzi, underscores the suffering caused by the divorce between his conscious, artistic will, and the works which impose themselves on him. "Ce qui fait que je vais si lentement," (Flaubert writes), “c'est que rien dans ce livre n'est tiré de moi, jamais ma personnalité ne m'aura été plus inutile... Saint Antoine ne m'a pas demandé le quart de tension d'esprit que la Bovary me cause..." (Flaubert 111). Yet Flaubert is the model of the author who leaves nothing to chance, weighing all, achieving exactly what he wants through patient elaboration and relaboration. His method is painfully analytical. On the surface, Tozzi seems the opposite, yet there are similarities, or perhaps antinomies which spring from the same root. The existentialist Sartre, in his study of Flaubert, L'Idiot de la famille, examines the analytical method in Flaubert, which, according to Sartre, is a manifestation of the domination of Flaubert père: "le père ennemi, installé en lui, comme une force étrangère, le domine et le dirige à son gré" (498). This analytical bent does not correspond to Flaubert's needs:

Voici donc l'analyse, comme schème opératoire, introduite sournoisement en Gustave et se substituant chez lui è l'expérience acquise, devenant, de par l'autorité paternelle, un impératif méthodologique et se prétendant équivalente à l'expérience existentielle. (488)

Leaving aside filial similarities, is this not, wholly inverted, exactly what happens with Tozzi? I mean that experience for him becomes the operative imperative, substituting all explicit analysis. Yet Tozzi, like Flaubert, is conscious of the imposition, doing his best to convert it to his advantage and, we know, succeeding. To hypothesize a Tozzi "more capable of dominating his work" is as useful, in evaluating his work, as imagining a Flaubert satisfied with a first draft. Tozzi's is an anti-analysis, an examination by imagery and metaphor; allegory, in the case of Gli egoisti, and, it might be said, all of his writing. There is throughout his work a studied insistance on the lack of, even a refusal of understanding, of impressions suffocating comprehension, of pure reaction, paranoic or ecstatic. We might amend Debenedetti's comment that Tozzi narrates because he cannot explain, and say he narrates by refusing to explain. Or by explaining in a new way. Why else, for example, the hyperbolic insistence, in 
this fragment from Bestie, on the lack of understanding of an event which few would remember, much less ponder for years?

Non so ancora spiegarmi, da otto anni, perché la mia amante, una volta, dopo aver bevuto la birra, chiudesse con il ventaglio aperto, dentro il suo bicchiere, una vespa che v' era entrata.

Prima era entrata nel mio; ed ella l' aveva guardata sorridendo, divertendocisi quasi. Io cercai di farle muovere il braccio, ma ella, con tutta la sua forza, non mi dette retta. Mi disse:

- Parliamo d' altro. (Bestie 602)

In another part of Bestie there is a series of impossible questions:

Ma perché, dunque, quando due briachi cantarono io non chiusi la finestra? Perché la loro voce mi dava una gioia irrefrenabile, una contentezza che non mi faceva star fermo? Sapevo forse spiegarmi quel che fosse avvenuto? Non potevo io aver ucciso molta gente? Di che cosa temei, all'improvviso? Perché non morii in quel momento di dolore? (588)

Tozzi seems more obstinate than inarticulate. Stated more logically, his major theme consists of calling attention to the limits of his characters' capacity, or even refusal, to apprehend general relations of particulars. In addition, Tozzi, as in the quote above, often puts together particulars which cannot be related. Again, it is a good idea to examine closely some of Tozzi's critical work, particularly the section of Realtà di ieri e di oggi called "Verità psicologiche." In the 1918 article entitled "Le nostre ombre" he writes: "quando il significato della nostra realtà è stato messo in moto, sarebbe difficile pretendere che continuassimo a fare una distinzione qualsiasi tra noi e quelle verità che vogliamo imporre" (Pagine critiche 102). The radical suspicion concerning the nature of reality renders truth entirely relative. Tozzi will extend his reflections on the nature of reality to the shifting character of a text. For Tozzi, a text, his own and others', is consubstantial with that natural reality which must remain inexplicable. There is no verum ipsum factum. Mobile, swaying, shattered, unreal, the world deters generalization; the text deters paraphrase. In carrying his attitude towards his own books and his method of reading the work of others, he uses a method of confounding or destroying the distinction between a system of signifiers (the book) with the world of the signified. Let us recall the metaphori$\mathrm{cal}$ and metonymic equation vineleaf=book in the narrative of Bestie discussed above. In another part of Bestie, the pair reappears:

\section{Quel che vedo e penso è come se lo leggessi.}

Leggerò, forse, fino a stasera; ma il libro non lo chiuderò: resterà aperto tutta la notte $\mathrm{e}$ troverò i sogni su le pagine come se fossero figure.

In vece, no. Allora percepisco solo le cose, che stanno vicine a me: e, perché sono seduto sotto la mia pergola, mi metto a guardare un pampino: forse, uno dei più larghi. Perché 
non capisco quel che fo, lo strappo dal tralcio e lo butto dietro di me, di là dal pancone verniciato di verde.

Il sole, tra gli altri pampini, taglia gli occhi con i suoi pezzetti di vetro.

Una cavalletta mi salta su una mano. (Opere 612)

Here, the real world and the mental world, like the world of dreams, are texts to be deciphered. Once again, the symbolic status of language is de-emphasized by turning everything to symbol, but for Tozzi one cannot observe this forêt des symboles with any regard of familiarity nor with any comprehension. If he consciously or unconsciously adopts allegory as his main figure, it is allegory without a referent, or a referent which is inscrutable. The image of reality as allegorical code is then refused ("In vece, no. Allora percepisco solo le cose...") in favor of direct perception, without the mediation of code, a world which, however, proves to be wholly inscrutable, which can be analysed, but without conclusion. The narrator's inability to decipher reality suscitates in him a blind, destructive violence as he tears away the vineleaf: symbol, elsewhere, of the book, or of world as book. But Nature remains inscrutable as the sun, unblocked by his violent action, cuts the narrators eyes with shards of glass and a locust (devourer of crops) jumps on his hand (and we should recall that the word "cavalletta" means also an importunate, troublesome being). 11 The world, which had seemed to offer itself for decoding, turns into an inscrutable block: of perceptions, or perhaps of enigmatic signs. "Perché quando il significato della nostra realtà è stato messo in moto, sarebbe difficile pretendere che continuassero a fare una distinzione qualsiasi tra noi e quelle verità che vogliamo imporre [...] Non ci può essere, nella vera letteratura, nessun orientamento spirituale," he writes in the essay "Le nostre ombre" (Pagine 102). Tozzi's authorial strategy consists of fashioning, as artisan, disorientation: a removal of bearings before the world as well as before literature.

What is at the root of this displacement? One analysis can be found in the following passage from Tre croci, rightly identified by Eduardo Saccone as central towards understanding the process of disorientation; central also, I think, in understanding Tozzi's metaphor-metonymy of book and vineleaf, word and world. Giulio Gambi (probably the most lucid of Tozzi's characters, the most aware of his predicament), against the backdrop of the whole of Siena (the world, for Tozzi) is speaking to the French Nisard:

Mi ricordo di quand'ero giovane. Bastava che restassi una mezz'ora solo e non avessi niente da fare, perché mi venisse una specie di sospetto che mi faceva paura. lo non ero né meno sicuro di vivere. 11 sospetto che avevo non glie lo so spiegare; ma cercherò di farglielo capire. Lei sognando, qualche volta, ha certamente avuto nello stesso istante una sensazione vaga, non si sa se con piacere o con dolore, che le impediva di credere al suo sogno; e avrebbe voluto che fosse stata la realtà, invece. Ma quella sensazione staccava il suo sogno, lo teneva discosto, senza riescire però a fare di lei stesso e del sogno una cosa sola. Ebbene la realtà - la chiamano realtà - che m'era intomo, mi faceva 
lo stesso effetto. Io non sapevo se quel che vedevo era un sogno più vasto, continuo, a cui mi ero abituato; e del quale soltanto poche volte avevo coscienza. Per farla capire meglio, immagini che il presente stesso era per me il senso d'una realtà convenzionale. (Opere 238)

Saccone correctly identifies the key word here as sospetto - the "sospetto radicale, che in qualche modo la [reality] sospende, la rende incerta, insicura, anche irreale" ("Cambiali" 166). And the suspicion we begin to entertain is that Tozzi, who confounds, willingly or unwillingly, the perceived irreality of the world with the radical irreality of the word, is aware, before his time, that a text, even his own, is as permanently inexplicable and unstable as the mobile nature of the elusive reality he describes. Giulio Gambi's suspicion, and that of the Tozzian character in general, does not even lead to the threshold of the level of cognizance of even the most "inept" of Svevo's personnages. The Tozzian protagonist's awareness is simply the verification of the stupor with which he reacts to instability. According to Borgese, "L'introspezione scava soltanto nell'emozione e nel dolore, ed è austera appunto perché incon-cludente e disperata; l'esame di coscienza, fatto ad occhi chiusi, è una discesa da palombaro entro un'umanità e una natura che reagiscono alla vita con contrazioni, ad altri impercettibili, di spasimo" (Debenedetti 220). The quote regards Con gli occhi chiusi, but is as true for any of Tozzi's characters. In fact Pietro Rosi is reported by Tozzi as possessing an awareness that he is, according to Debenedetti,

...un recluso dietro quella frontiera che sono gli occhi chiusi: la quale lo taglia fuori dalla realtà giudicabile, agibile, che è la vita concreta, condivisa con gli altri, "prigioniero", dice con esclamazione dolorosa, di "quella sua vita interiore che gli si sopprapponeva sempre!" E la sua mancanza di presa efficace, attiva, è constatata fin da subito: "gli pareva che le persone intorno a lui agissero come nei sogni." (Debenedetti 223)

Is not considerable detachment required in order to create characters and situations illustrative of this condition? In contrast, Svevo's characters, though treated with more perceptible irony, are closer to their author; one mark of their great difference (besides the fact that the Svevian protagonist is usually a writer, an activity inconceivable for the Tozzian counterpart) is the fact that Zeno Cosini is armed with the tools of Freudian analysis, although his use of them is suspect in terms of the degree of self-awareness thus attained. (Luigi Baldacci is right in pointing out that as regards authorial strategies, Svevo, especially in Zeno, speaks the koine of modern culture, which is still our language, while Tozzi, in comparison, is willfully primeval, though the very fact that he has remained pre-Freudian, while his analytic method, which divines the same material, is modern, gives him an advantage, in the long run, over the Triestine. $)^{12}$

So Tozzi "rappresenta in quanto non sa spiegare." In considering Tozzi's 
important essay "Come leggo io," most critics have singled out the following passage:

Ai più interessa un omicidio o un suicidio; ma è egualmente interessante, se non di più, anche l'intuizione e quindi il racconto di un qualsiasi misterioso atto nostro; come potrebbe esser quello, per esempio, di un uomo che a un certo punto della sua strada si sofferma per raccogliere un sasso che vede e poi prosegue la sua passeggiata. (Opere 1325)

Emphasized by Tozzi by its placement in italics, the word misterioso has also been featured in support of the view concerning the author's uncomplete dominance over his material. But Tozzi here speaks precisely of "l'intuizione," that is, of the realization and expression of a fact without the aid of a rational, deductive or inductive process. And by simple statement, narrative is inferred: "l'intuizione e quindi il racconto." Narrative is identified with, and born out of, the absence of exegesis. The author continues:

Con il mio sistema, che del resto è soltanto per mio uso e consumo, io scompongo intuitivamente qualunque libro; e posso, senza scomodarmi, tener d'occhio lo scrittore in tutti i suoi elementi. Così, ci vuol poco anche a sentire quanto "pensiero" c'è dentro; perchè il temperamento di un qualsiasi scrittore si conosce soltanto mettendolo a prove decisive. (1325)

It does not appear that Tozzi is here indicating an absence of control over his writing, a removal of responsibility and of author or authority, but on the contrary a close division between what he considers the essential and the accidental in his construction of narrative. Seen in this way, the insistence in "Come leggo io" on both artisan-like maitrise and the mysterious is not contradictory but, simply, a way of stating that a given subject matter calls for certain stylistic approaches. I mentioned Joyce some time ago. The imitative techniques so successfully employed in Ulysses in rendering the subconscious mind, and the stylistic incorporation of the novel's themes, can, I think, be quite rightly compared to Tozzi's deployment of imagery in novels like Con gli occhi chiusi, where the protagonist is, in Tozzi's words, "prigioniero di quella sua vita interiore che gli si sopprapponeva sempre."13 Tozzi's, like that of Joyce, is one of the destructive discourses of the early twentieth century, and "Come leggo io" may be read as, if not a manifesto, a notice of heterodoxy. It would be a mistake, in approaching Tozzi's work, to entertain the notion that there is a sort of exegetical, ideological center that defines, gives meaning, designates and holds the structure together, or that Tozzi wished for, but could not form, that center. Decenteredness is a main theme. The restlessness of Tozzi's transcription is a technical device; the series of unanswered questions in Bestie ("Sapevo forse spiegarmi quel che fosse avvenuto? Non potevo io aver ucciso molta 
gente? Di che cosa temei, all'improvviso? Perché non morii in quel momento di dolore?") the intuitive foundation of an epistemology (to which we are growing used today) based on the lack of center, of ideology.

\section{The Johns Hopkins University}

\section{NOTES}

] The new "percezione intima e spirituale," Tozzi writes, makes for "maturazioni stilistiche che ormai non possono tardare, perché coincidono con nuovi stati d'animo." See Tozzi, Realtà 54.

2 See, for example, Ferroni 116-23, where the critic and historian repeats Debenedetti's formula. See also Saccone, Conclusioni 82, in which Tozzi's automatism is discussed; also Balducci where biografismo is a main component, as well as recent essays by Pampaloni and others in Per Tozzi.

3 It should be noted that in many segments of Bestie the narrating "io" presents a family history quite different than that of the author: clearly the book is not meant as autobiography. See also Tozzi, "Autorecensione" 191-92.

4 For the most benign interpretation of Tozzi's incapacity, see Debenedetti 55-107 and 125-256; in particular the pages on Con gli occhi chiusi 202-39. An example from Debenedetti 161: "La disperata situazione che fa di Tozzi un narratore è proprio l'incapacità costituzionale che egli ha di assimilare quel passato...."

5 An example of this erroneous stance is in Sapegno: “... erano negate al Tozzi sia la possibilità di obbietivare i dati della sua psicologia in forme narrative, in personaggi e vicende capaci di una almeno relativa autonomia... una sensibilità ancora indiscriminata e priva di giustificazioni, assai più vicina insomma al documento umano che non all'opera d'arte" (390). See also Gargiulo 82.

6 See Saccone "Le allegorie" (82), in which there are the following allusions to automatism: the "impersonalità, che esclude l'intervento della volontà del soggetto, o quanto meno la pone fortemente in questione, non però alla maniera di un naturalista, piuttosto di un surrealista, o una sorta di scrittura automatica in effetti, o sotto dettatura." And again: "... questo accecamento, questa chiusura degli occhi che gli ha pur permesso di vedere" (77). And: "Sarebbe troppo facile sbarazzarsi di un tale testo invocando la scarsa capacità, o addiritura l'incapacità di Tozzi a mettere insieme un coerente discorso intellettuale" (81). Saccone, however, compares Tozzi accurately to the figure of sorcerer, who may be a careful technician, but who unleashes powers superior to himself. This is still, of course, a description of the act of writing in general.

7 Tozzi is quoted in Pampaloni 99. See also Tozzi's essay "Arturo Rimbaud" in Pagine 307: "Il Rimbaud procede... per mezzo d'immagini la cui sensibilità logica bisogna cercarla in certi inattesi significati, a cui una musica intima e compatta aggiunge una specie di fascino. La sua poesia è una delle meno analizzabili e una delle più indovinate..."

8 See Saccone, "Le allegorie" 81 . The critic does caution, it is true, against dismissing Tozzi's pronouncements as naive, which is perhaps to say that in his critical writing, Tozzi uses a language which has not yet been understood. Certainly the question of what Tozzi meant by such words as "lirica," "parola" and "anima" has not yet been convincingly answered.

9 See on this point Saccone "Le allegorie" 94: "Quanto al tempo - ed è il secondo punto che discende o si accorda col primo - quello di cui qui è questione non è né un presente, né un passato, o un futuro referenziali, ma un tempo allegorico, un tempo puramente narrativo: il tempo della narrazione. [...] presente, passato e futuro si alterano senza che nulla veramente cambi o importi..." See also Tozzi Novale, especially the letters dated 9/29 and 12/15, 1907.

10 This quote from Flaubert is the jacket blurb for the Seuil edition, in 2 vols., of his Oeuvres Complètes. Paris: Éditions de Seuil, 1964.

11 Equivalence vineleaf/book also in Tozzi: “...dirò che un periodo scritto male ma di buono 
scrittore, si distingue subito da un periodo scritto male da cattivo scrittore. Non è possibile ingannarsi, quando s'ha un poco di pratica!... come il contadino che al colore del pampano riconosce se la vite è stata assistita o no" ("Come leggo io" 9).

12 Cited in Luti (X1).

13 Samuel Beckett wrote of Finnegans Wake: "Here form is content, content is form... His [Joyce's] writing is not about something, it is that something itself... When the sense is sleep, the words go to sleep" (14).

\section{WORKS CITED}

Balducci, Alberto. Il nucleo dinamico dell'imbestiamento. Anzio: De Rubeis, 1994.

Beckett, Samuel, et al. Our Exagmination Round His Factification for Incamination of Work in Progress. New York: New Directions Books, 1962.

Cesarini, Paolo. Tutti gli anni di Tozzi. Montepulciano: Editori del Grifo, 1982.

Debenedetti, Giacomo. Il romanzo del novecento. Milano: Garzanti, 1971.

Ferroni, Giulio. Storia della letteratura italiana. Il novecento. Torino: Einaudi, 1991. 116-23.

Flaubert, Gustave. Extraits de la correspondance ou Preface de la vie d'écrivain. Paris: Éditions du Seuil, 1963.

Gargiulo, A. Letteratura italiana del novecento. Firenze: Le Monnier, 1940. 82-85.

Luti, Giorgio. "Introduzione," to Federigo Tozzi. Opere. IX-XXXII

Pampaloni, Geno. “Tozzi critico.” Per Tozzi. Roma: Editori Riuniti, 1985. 98-105.

Saccone, Eduardo. Conclusioni anticipate su alcuni racconti e romanzi del novecento. Napoli: Liguori editori, 1988. . "Le cambiali di Tozzi". Modern Language Notes 104 (1988): 151-88.

. "Le allegorie di Tozzi". Modern Language Notes 108 (1993): 87-112.

Sapegno, Natalino. Storia della letteratura italiana. La letteratura del Novecento. Milano: Garzanti, 1987, 2 vols.

Sartre, Jean-Paul. L'idiot de la famille: Gustave Flaubert de 1821 à 1857.3 vols. Paris: Gallimard, 1971-2.

Tozzi, Federigo. "Arturo Rimbaud." Pagine critiche 307-12.

-_._Autorecensione a Bestie." Pagine critiche 191-2.

. "Come leggo io." Opere 1324-7.

Con gli occhi chiusi. Opere 4-158.

Cose e persone. Firenze: Vallecchi, 1981.

Gli egoisti. Opere 449-504.

"Le nostre ombre." Pagine critiche 101-4.

Novale. Firenze: Vallecchi, 1984.

Opere. Milano: Mondadori, 1987.

- Pagine Critiche. Pisa: Edizioni ETS, 1993.

. "Per l'arte di Grazia Deledda." Opere 1284-88

- Quel che manca all'intelligenza." Opere 1280-83.

. Realtà di ieri e di oggi. Montebelluna: Edizioni Amadeus, 1989.

Yeats, W.B. A Vision. London: Arena Press, 1990. 